\title{
The situation of Vocational and Technical Education in Jordan and Japan: A Comparative Study
}

\author{
Ibtisam Mustafa Falah Alomari \\ Department of Applied Science \\ AlBalqa Applied University \\ Irbid University College \\ E-mail: Ibtesamalomari@bau.edu \\ Khawla Mahmoud Nahar Alalwneh \\ Department of Education \\ AlBalqa Applied University \\ Irbid University College \\ E-mail: khawla-alawneh@bau.edu.jo \\ Maaly Mefleh Mohammed Al-Mzary \\ Department of Applied Science \\ AlBalqa Applied University \\ Irbid University College \\ E-mail: maaly-al-mzary@bau.edu.
}

\begin{abstract}
The purpose of this study is to compare the experiences of both Jordan and Japan in terms of the provision of vocational and technical education, through the use of the qualitative method and reviewing of related literature. The comparison is organized in three sections, the first of which is related to the history and development of vocational and technical education in the two countries. The results related to this section showed the short history of the Jordanian experience compared to the experience of Japan. The results of the second section, which is related to the organizational and institutional aspects of the experiences of the two countries, showed that some similarities and also some differences which were on behalf of the Japanese experience. Finally, concerning the challenges facing vocational education in the two countries, results showed that both countries face several challenges which require improving developing the provision of vocational and technical education in the two countries.
\end{abstract}

Keywords: Vocational and Technical Education, Educational Institutions, Educational Programs.

\section{Introduction}

Several countries worldwide sought to make vocational education an essential part of their curricula, based on its effective role in contributing to the formation of the personality of the student, in all its aspects. Through vocational education, students acquire various skills which are relevant to their everyday life, and positive attitudes towards manual work and workplace (Al-Sa'aideh \& Al-Mahasneh, 2015).

Due to the variation in the history and development of vocational and technical education in different countries (AlSamman, 2012), international experiences can be used in order to develop education at the national level. Japan has a remarkable experience in terms of vocational education, with dates back to more than a century, which explains why it became a destination for students from various countries worldwide. Studies found that 916\%) of the students of vocational education are from foreign countries, most of which Asian (Tsukamoto, 2016).

This study aims to provide a comparison between Japan and Jordan in terms of vocational and technical education, through reviewing the stages of development, and analyzing the organizational aspects of the experiences of the two countries, as well as the prominent problems relevant to vocational education in the two countries.

\section{Problem of the Study}

Vocational and technical education in Jordan face several problems and challenges, which require systematic and scientific research in order to arrive at suitable solutions, to be applied based on the results of such studies. 
The successful experiences of countries can be considered as a source for solutions to problems related to vocational education. In this age, which is characterized by easy access to information, the experiences of countries can be reviewed and adopted by other countries worldwide. Success in terms of vocational education is reflected in economic development, through the provision of qualified human resources, which have the required sufficiency required for contributing effectively to the economic development. The current study seeks to identify the aspects of the Japanese experience in terms of vocational education, and comparing that experience to the experience of Jordan, in order to identify the main differences between the two countries, as well as identifying the positive aspects in the two experiences so that they can be used in order to improve the Jordanian experience in terms of vocational and technical education.

\section{Aims of the Study}

This study aims to:

- Identifying the most important stages in the development of vocational education in Jordan and Japan, and pinpointing the main differences.

- Analyzing the regulatory and organizational aspects of vocational and technical education in both countries, and the main relevant differences.

- Identifying the essential challenges faced by vocational education in Japan and Jordan.

\section{Method of the Study}

This study employs the qualitative method in collecting and analyzing the data related to the problem of the study, through a revision of documents and literature, in order to answer the questions of the study.

\section{Stages and milestones of the development of Vocational education in Jordan and Japan}

Vocational education is relatively new in Jordan, with its few decades of age, compared to Japan whose experience dates back to more than a century. From 1950 to 1978, the ministry of education in Jordan provided a simple form of vocational education for the classes 7-10, in some schools only, under the name "vocational activity", with two weekly classes in total, and with a total time of 1.5 hours. The topics taught in male schools of males were different from those taught in the schools of female students. Female students studied topics related to family economy, sewing and embroidery, while male students studied topics related to agriculture, industry, and business. General guidelines were published without the presence of written curricula (Al-Saydeh, 2002).

Vocational education as a term was adopted in the period 1979-1990, and several schools were not required to teach the subject, which was not an obligatory school subject. The main factor in this case is the existence of facilities, and two weekly classes were devoted to the subject in total. The lack of textbooks and written curricula was the main feature until 1987 (Mahasneh, 2010, 2011). The period which continued in the years before 1987, was experimental, without written curricula, while from 1987 curricula were prepared and the vocational education became a compulsory school subject (Jawarneh, 2010)

Approximately, third of the graduates of elementary education in Jordan, go for vocational education nowadays (26\%), with no opportunities for higher education upon graduation from school. However, $25 \%$ of the graduates of vocational education study at community colleges, and (4\%) of the graduates of vocational education at colleges continue their study at universities (Habashneh, 2014). The ministry of education has recently eliminated the subject of vocational education for the first three elementary classes, a decision that may have an impact on vocational education.

The first legislation related to vocational education was approved in Japan in 1899, through which vocational education became an obligatory school subject in public schools. The topics taught in the first years following the legislation were related to agriculture, fishing, and simple handcrafts. The provision of vocational education to elementary school students continued until 1958, the year in which vocational education began to be provided to the students of secondary schools at comprehensive schools and at vocational schools. 50\% of schools provide academic education, and 50\% are devoted to vocational or comprehensive education (Murata \& Stern, 1993). In general, 26\% of secondary stage students in Japan go for vocational education in secondary school, a percentage similar to Jordan (Tsukamoto, 2016).

Vocational education in Japan is provided through two different streams, through which students acquire similar levels of vocational skills. In the first stream, students apply for technical colleges (which were launched in 1960), after their graduation from higher elementary school, at the age of 15 years, and their study at these colleges extends for five years. In the second stream, students join Junior colleges, in which study is provided in two years. Graduates of technical and junior colleges can apply for technical universities in order to complete their higher education. 
In most vocational education programs in Japan, $70 \%$ of the study subjects are devoted to specialized vocational subjects, with the remaining percentage (30\%) devoted to Math, Japanese, and foreign languages (Goodman, Hatakenaka, \& Kim, 2009; Kariya, 1999).

Vocational education in Japan is characterized by systematic and regular planning. The ministry of labor conducts an annual scan in order to identify the skills lacking in the labor market, through correspondence with a sample of factories for the purposes of identifying their needs. Consequently, a five year plan is prepared, with every governorate from among the 47 governorates in Japan, preparing its plan through the technical training council of the governorate. Technical colleges in Japan qualify students, and contribute to science through research. Research is also funded through cooperation between colleges and local industry, through which colleges contribute to the development of industry and the society in general. Research related to the problems of industries contributes to the improvement of the content of educational programs, which is reflected later on curricula and education through the educational faculties participating in research (Al-Ansari, 2015).

\section{Regulatory and organizational Aspects of vocational education in Jordan and Japan}

Balqa Applied University was established in 1997, according to Act (13), in order to prepare academically and technically qualified human resources at the university level and intermediate level. Through that Act, the administration of community colleges was became the responsibility of Balqa Applied University. The university seeks to develop the colleges, through the development of their study programs, curricula, and facilities. The university study programs are provided through semesters and study hours, and the degrees of B.A, M.A, Intermediate degree, and Diploma are provided in various specializations approved by the council of higher education in Jordan, as well as the union of Arab universities.

The vision of the university states that it is focused on providing qualitative educational opportunities in order to prepare qualified human resources at intermediate and university levels and supporting the applied aspect in the various study programs and the academic levels. Balqa University consists of 18 colleges, 6 of which are located within its campus in Salt Governorate, and 12 colleges in most of the remaining Jordanian governorates. The university also undertakes the task of supervising the other community colleges in Jordan, whether they are private, military, and public or international, whose number is 38 , with various study programs. The university contributes also to the improvement of vocational education for school age students. The university introduced its B.A program in vocational education in 2002, which is a unique specialization in Jordan that is needed in the labor market, especially for teaching at elementary stage schools, in which vocational education is a school subject (Mahasneh, 2010, 2011).

The technical and vocational training corporation was established in 1978, based on Act (11) of 1985, and the Act of vocational Work number (27) of the year 1999. The corporation has a management board headed by the minister of labor, with two members, who represent the private sector, and 6 members who represent the public sector, including the manager of the corporation, as well as three members who represent the organizations of the local community. The corporation provides qualitative programs, 200 in total, divided into levels (professional, skilled, limited skilled) in addition to diploma program which is provided in cooperation with Balqa Applied University, and the Life Long Learning program, in various areas including medical professions, Water, Environment, Renewable energy, Tourism, Security, information technology, communications, among others. The period of study ranges from one training semester (700) hours, to four training semesters (2800) hours (Habashneh, 2014).

Unlike other organizations that provide vocational education, the technical and vocational training corporation works in cooperation with the private sector, which is the major recipient of its outcomes. The representatives of the private sector participate in decision making through the management board as well as the committees, in all the strategic, technical, executive and planning levels. The private sector assists also in designing and applying training programs, especially the Dual System Training Program, which is the main training program at the corporation, and in which trainees spend $50 \%$ of the study time in actual workplaces.

Vocational programs in Jordan are provided through two main systems, and two levels, the first system targets the graduates of elementary stage schools, at the age of 16-18 years. This system prepares skilled workers and professionals, through two streams: the comprehensive stream, which consists of two branches: academic and vocational, and which covers more than 40 specializations. The second branch is based on applied secondary education, which is managed and executed through the technical and vocational training corporation with the cooperation of employers from the private sector. The second system targets the graduates of secondary schools, at the age of 18-21 years, with the purpose of preparing technicians (assistants of professionals) at the level of diploma (Habashneh, 2014). 


\section{Challenges Facing vocational education in Jordan and Japan}

One of the main challenges facing vocational education in Jordan is the divided responsibility concerning that education in terms of planning, application, assessment and funding, among several public and private agencies, which provides the services of employment, training, and education, as well as the cultivation of skills.

Those agencies include the ministry of education, The technical and vocational training corporation, ministry of labor, the National Employment and Training Firm, the specialized Funds (such as the Employment, Education and Training Fund, and the Training and Employment FUND), as well as the community colleges and the private sector (Habashneh, 2014).

Vocational education in Jordan lacks also an effective backing which enables it to cope with the rapid economic changes, which is due to the fact that it is based on a model which was designed in 1970s, and is characterized with a high degree of centralization. Vocational education programs in Jordan are prepared without an encompassing national strategy related to the needs of employers. The low level of participation by the private sector in the system of vocational education in Jordan resulted in a lack of compatibility between the outcomes of the educational system and the needs of employers. A comprehensive vision concerning Life Long learning is also lacking, coupled with a lack of an appropriate Counseling System.

Facilities and educational means at educational institutions are also insufficient, and trainers lack the required skills, in addition to the limited autonomy of the providers of training, especially in terms of the development and applying the programs of lifelong learning (Al-Sa'd, 2007).

Studies suggest that graduates of vocational education have insufficient levels, which is ascribed to the gap between the curricula and the needs of the market (Al-Soyouf, 2007).

Concerning the vocational education for the elementary stage, the content of the curricula is divided into six areas (Agriculture and environment, engineering skills and simple maintenance, Health and personal safety, economy and technology, hospitality and tourism, and household issues), which makes the task of preparing a qualified teacher qualified for teaching the relevant topics difficult, because of the complexity and variability of duties he undertakes, which includes teaching, preparing the practical activities, supervising the workshops, providing counseling to students, as well as the productive work in the vocational workshops (Mahasneh, 2011).

Based on the lack of sufficient numbers of specialized vocational education teachers, unqualified teachers are sometimes hired for teaching vocational education subject at schools (Al-Saydeh, 2002).

Recently, the ministry of education made attempts at developing the curricula of vocational education, and a specialized department was established for the subject at the ministry, in order to identify the requirements and needs related to teaching vocational education. Despite the introduction of vocational education at the elementary stage, the attitudes of the students towards the subject is negative, which reflects a similar attitude among the parents of the students as well as the school administrations and teachers, which explains dropping the classes of vocational education at some schools, and putting it at the end of the school day at other schools, despite the low level of motivation among the students at the end of the school day (Hazaimeh \& Ismael, 2014, 232).

Another important challenge concerning vocational education in Jordan is related to the fact that most students who go for vocational education do so without motivation and persuasion, because they are embraced for the separation between academic and vocational education, in addition to their ignorance about the nature of vocational education, as well as the lack of sufficient counseling (Al-Twaisi, 2013).

Another factor which contributes to the phenomenon is the lack of correspondence between the vocational education in one hand and the real situation and requirements of vocations in the market (Al-Alawneh \& Mustafa, 2014), which results in the inability of graduates to compete in the market (Al-Halaby, 2012; Al-Saaideh, 2016).

Al-Saaideh (2016) explains the students abstaining from joining vocational education based on the vocations themselves, in addition to personal factors related to the students' preference for academic education. The impact of peers is also another factor which explains students refraining from vocational education, in addition to the low income of such vocations in the market (Al-Sa'd, 2007). The negative image of vocational schools is another factor in this context (Miqdadi, 2007).

Teaching vocational subjects in Jordan has its challenges also, which includes the lack of appropriate workshops, the lack of specialized teachers, the negative attitudes of headmasters, teachers and students towards vocational education, and the large numbers of students in classes (Al-Saaideh \& Mahasneh, 2015). 
In both Jordan and Japan, students and their parents show preference for academic programs compared to vocational programs, which makes vocational education a second option, chosen by those students with low academic achievement and who belong to the lowest economic and social classes.

The number of universities in both Jordan and Japan has increased since 1980s, with 800 universities in Japan now and tens of universities in Jordan. Additionally, vocational educational programs provided at universities have acquired respectable status recently (Tsukamoto, 2016; Fujikawa, \& Maesako, 2015).

Another common challenge facing vocational education in Jordan and Japan is the reduction and deterioration in the contribution of the private sector during the last years, which is ascribed in the case of Japan to outsourcing strategies adopted by the Japanese firms (Tsukamoto, 2016).

\section{Recommendations:}

Based on the results of the study, the researchers recommend:

- Conducting additional comparative studies which aim to identify the positive aspects of the various educational systems in terms of vocational education in order to improve the vocational education in Jordan.

- Performing a regular scan for the purposes of identifying the needs of the local Industrial and Service sectors in terms of the skills, and using the results in designing and updating the educational programs at the various educational institutions.

- Enhancing and supporting the participation of the private sector in designing the educational vocational programs at the various educational institutions, as well as in providing Field training and employment for the students of those programs.

\section{References in Arabic:}

Al-Ansari, I. (2005). Modern Trends in Vocational Education and Their Application in Arab Countries. A paper submitted in the first Arab Conference for the Future of Vocational Education in the Arab World, Arab Administrative Development Organisation, Arab League, 175-206.

Al-Halaby, S. (2012). The Situation and Problems of Vocational and Technical Education in the Arab World: a case study of Syria. Al-Quds Open University Research Journal, 28(2), 397-434.

Al-Sa'aideh,M., \& Al-Mahasneh, O.(2015). The Problems Facing the Students of Vocational Education at Balqa Applied University During Field Training. Dirasat, Educational Research, 42(1), 13-29.

Al-Samman, Z. (2012). A Comparative Study of Secondary Vocational Education in USA, Egypt and Syria. Thesis, University of Damascus.

Al-Soyouf, M. (2007). The Degree of Emphasis on the requirements of Vocations within the Industrial Education Curricula, and the degree of their Acquisition By the Graduates. Dissertation, Jordanian University.

Al-Twaisi, A. (2013). Proposed Solutions for the Improvement of Societal Attitudes towards Vocational Education from the Perspective of Experts in Jordan. Dirasat, Educational Research, 40(2), 1493-1510.

Habashneh, M. (2014) The Role of The Technical and Vocational Training Corporation in Training and Employment. Al-Rai Newspaper, 26/11/2014.

Hazaimeh, Z., \& Ismael, N. (2014). Teaching Vocational Education at the Elementary Stage and its Role in developing the Attitudes of Students towards Vocational Education from the Perspective of Vocational Education Teachers in Jordan. Taibah University Journal for Educational Research, 9(2), 230-246.

Mahasneh, O. (2010). Basics of Vocational Education. Cultural World Publishers, Amman.

Mahasneh, O. (2010). Curricula of Vocational Education and their Teaching and Evaluation Strategies. Cultural World Publishers, Amman.

Ministry Of Education. (2008). General Guidelines for the Curricula of Vocational Education. Department of Curricula and Textbooks, Amman.

Miqdadi, O. (2007). Vocational Education in Jordan: its Problems, and Development Trends. Dissertation, Sudan University of Science and Technology, Sudan.

Tawalbeh, H., \& Alawneh, M., \& Al-Rifa'I, A. (2014). The Level of Inclusion of the Concepts of Vocational Education in the Curricula of National and Civil Education for the Higher Elementary Stage in Jordan. AlManarah Journal, 20(2b), 203-220. 


\section{References in English:}

Al-Alawneh, M., \& Mustafa, J. (2014). The Integration of Knowledge, Economical, and Technological Concepts in the Pre-Vocational Education and Sciences Education Curriculum as Perceived by the Teachers at Irbid Directorate Schools. Jordan Journal of Educational Sciences, 10(2), 249-259.

Al-Saaideh, M. (2006). Reasons for Avoidance of Vocational Education in Jordan. Educational Research and Reviews, 11(11), 1064-1084.

Alsaaideh, M. (2014). Educational demands to reduce avoidance of vocational education in Jordan. Educational Research and Reviews, 11(8), 598-622.

Al-Sa'd, A. (2007). Evaluation of students' attitudes towards vocational education in Jordan. doctoral dissertation, Malmo University.

Al-Saydeh, M. (2002). Pre-vocational education in Jordan: implications for teacher preparation and in-service training. Doctoral dissertation, University of Huddersfield.

Fujikawa, S., \& Maesako, T. (2015). Present Situation and Problems of Technology Education in Japan: With Focusing on Technology Education as General Education. International Research in Education, 3(2), 173-182.

Goodman, R., Hatakenaka, S., \& Kim, T. (2009). The changing status of vocational higher education in contemporary Japan and the Republic of Korea. Discussion Paper Series (4), UNESCO.

Jawarneh, T. (2010). Status of Prevocational Education (PVE) in Jordanian Elementary Schools as Reported by Elementary Teachers. Dirasat: Educational Sciences, 34(2), 442-456.

Kariya, T. (1999). Transition from school to work and career formation of Japanese high school students. International Perspectives on the School-to-Work Transition, Hampton Press, Cresskill, NJ.

Murata, S., \& Stern, S. (1993). Technology education in Japan. Journal of Technology Education, 5(1), 29-37.

Tsukamoto, K. (2016). Vocational Education and Training (VET) in Japan. Departmrnt of Education and Training, Australian Government. 